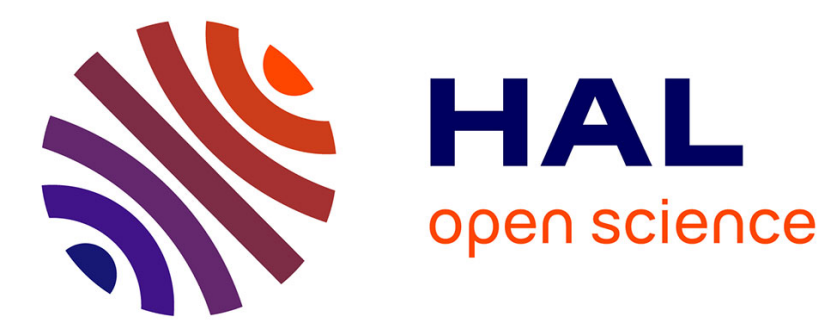

\title{
Modelling the risks of natural stand closure release with ageing in pure beech (Fagus sylvatica) and spruce (Picea abies) stands \\ Schütz, Saniga
}

\section{- To cite this version:}

Schütz, Saniga. Modelling the risks of natural stand closure release with ageing in pure beech (Fagus sylvatica) and spruce (Picea abies) stands. Annals of Forest Science, 2011, 68 (6), pp.1105-1114. 10.1007/s13595-011-0126-7 . hal-00930696

\section{HAL Id: hal-00930696 https://hal.science/hal-00930696}

Submitted on 1 Jan 2011

HAL is a multi-disciplinary open access archive for the deposit and dissemination of scientific research documents, whether they are published or not. The documents may come from teaching and research institutions in France or abroad, or from public or private research centers.
L'archive ouverte pluridisciplinaire HAL, est destinée au dépôt et à la diffusion de documents scientifiques de niveau recherche, publiés ou non, émanant des établissements d'enseignement et de recherche français ou étrangers, des laboratoires publics ou privés. 


\title{
Modelling the risks of natural stand closure release with ageing in pure beech (Fagus sylvatica) and spruce (Picea abies) stands
}

\author{
Jean-Philippe Schütz $•$ Milan Saniga
}

Received: 3 September 2010 /Accepted: 12 April 2011 / Published online: 25 August 2011

(C) INRA and Springer Science+Business Media B.V. 2011

\begin{abstract}
- Background In the development of pure beech and pure spruce pristine forests, we assume there should be a continuous transition from full stocking to successive disintegration and, finally, total replacement of the first generational wave at the end of its lifetime, dependent on mortality due to overcrowding as well as ageing, leading newly recruited cohorts to grow up from below.

- Material and methods A survey of stem number distribution from permanent plots measured repeatedly in six pristine beech reserves and four spruce reserves, mainly in Slovakia, was considered as well as surveys from yield plots in untouched stands in Switzerland on comparable site conditions. From 64 (54, respectively) surveys in virgin forests, we separated (if necessary) the original regeneration waves from successive waves for calculation of stand density development. Comparison with a previous model for full stand closure according to Reineke's density rule allowed the risk of stand release to be evaluated and determined.

- Results The risk of stand closure release is substantially higher for spruce than for beech because of differences in longevity and in vulnerability to storms. Decay does not seem to be the decisive factor, until advanced ageing is
\end{abstract}

Handling Editor: Matthias Dobbertin

J.-P.S is professor emeritus, ETH Zurich

J.-P. Schütz $(\bowtie)$

Brüggliäcker 37,

8050 Zurich, Switzerland

e-mail: jph.s@bluewin.ch

M. Saniga

Faculty of Forestry, Department Silviculture,

Technical University Zvolen,

Zvolen, Slovakia reached. Consequences for the understanding of natural forest dynamics, especially reinitiation through successive waves of regeneration are drawn on the basis of silvicultural expertise from continuous cover systems. The density threshold limit for the accession of a second growth in the upper storey is attained at an age of about 180 years for beech and 140 years for spruce. This corresponds to about $70 \%$ or $40 \%$ of the life cycle, respectively.

- Conclusion Vulnerability to stand release should be considered as a gradual (discrete) rather than a continuous phenomenon that depends on the complex relationship between the collective cohesion within a stand and a propensity for weakening factors. This suggests that the establishment of large disclosure patches could be the driving force in the renewal of these virgin forests.

Keywords Risk management · Stand density · Virgin forest $\cdot$ Ageing $\cdot$ Continuous forest

\section{Introduction}

Risks represent a key factor for planning, particularly in long-lasting systems like forests (Hanewinkel et al. 2011). Until now they have seldom been assessed from a global standpoint, but have instead been viewed specifically as different disturbance factors, and almost never from the point of view of ontogeny, i.e., the fact that all living organisms die naturally at a certain time. However, there must be strong interactions between risk factors and ageing (Moorby and Wareing 1963).

When considering risks as a whole they should be distinguished into triggering factors, predisposition, and aggravating (exacerbating) effects. Interaction between these forces complicates a comprehensive analysis. The 
prevailing wisdom is that triggering factors (in temperate latitudes, typically storm events) are highly stochastic. The application of probabilistic analysis methods, well used in the insurance sector, is not usual in forestry, mainly because it requires enough data on disturbances on a very large scale in space or time, as well as information on life limits, which is mostly lacking, and because timber-production-oriented forestry shortens the natural life cycle. Long-lasting studies of life duration in untouched forest are generally lacking.

Growth models generally consider only fully stocked stands and very regularly thinned ones and avoid irregular ones as well as disintegration phases. Only densitydependent mortality has been studied in more detail, after Reineke (1933) first developed a method for assessing it correctly. This kind of natural initial elimination is due essentially to competition for space and resources, and affects low social tree classes, whereas suppressed classes die out due to a lack of resources because space occupancy increases with growing tree dimensions. However, the linearity of Reineke's rule as a straight line in a double logarithmic grid has recently been disputed (Zeide 1985, 1987; Weller 1987; Lonsdale 1990; Pretzsch 2006), as has taking the right outer edge of the $N$ to $d_{\mathrm{g}}$ data distribution (Schütz and Zingg 2010). A more parabolic convex course for this phenomenon seems more appropriate, mainly from the point of view of statistical representativeness. Whether this observation depends solely on changes in allometric conditions with increasing age or is due more to a first imperceptible disappearing of single trees because of laterstage mortality (competition independent) is not very evident, although it is considered in some mortality models (Ďursk 1997). Nevertheless, we assume that, according to observations in pristine forests, there should be a continuous transition from full stocking to successive disintegration and, finally, total replacement of the first cohort at the end of the lifetime even while newly recruited cohorts develop from below due to reinitiation.

Research in virgin (pristine) forest in central and western temperate Europe has a long tradition; eminent silviculturists such as Leibundgut (1959), Mayer (1978), and Pintarič (1978) stated that knowledge of natural dynamic processes should act as a reference for designing close-to-nature silvicultural treatments. Over the last 50 years, long-term surveys of virgin forests repeated in plots from different chronosequences (phases) that are inventoried periodically have permitted their natural stand dynamics to be generalized. In comparison to the old growth on the American continent, temperate European pristine forests contain only a very few tree species. On a large scale they are more or less monospecific. This is the case for the pure beech forests representing the main constituents of the climax of the forest system in temperate Europe (Ozenda 1994). In Germany, $61 \%$ of the forest is estimated to be pure beech ecosystems (Spellmann 1999). In the same way, at higher elevations, pure spruce forests also represent the climax of the forest system. This fact has two important consequences: first, in monospecific forests, the life cycle is characterized much more by the ontogenic particularities of the species, especially life duration, than in naturally mixed forests. In fact, the mixture contributes to more differentiation because of the highly differing longevities of tree species intermixing together and undergoing demise at different times. Second, monospecific natural pristine forests are particularly apt to be compared with existing growth models, which are usually available for each species on a separate basis.

Korpel' (1995) gives a general scheme for a comprehensive understanding of the life cycle of pristine forests (Fig. 1). After disintegration of the previous generation, a stand at first grows compactly, constituting a regular fully stocked stand (phase of growing or aggradation) until the so-called optimal phase (Fig. 2). With increasing ageing (after about 120 years), there begins first a more or less dispersed stem-by-stem opening of the cover, comparable to top thinning or shelterwood cutting in harvested forests, albeit not so regular, and, once the overstorey cover is sufficiently reduced, letting a new generation of the same species grow from below. With increasing senescence, the main cover disintegrates in irregular openings of variable size (between 0.2 and 0.5 ha in the case of beech forest, Fig. 3). Depending on the distribution and width of the opening, this leads to an irregular intermixing of successive

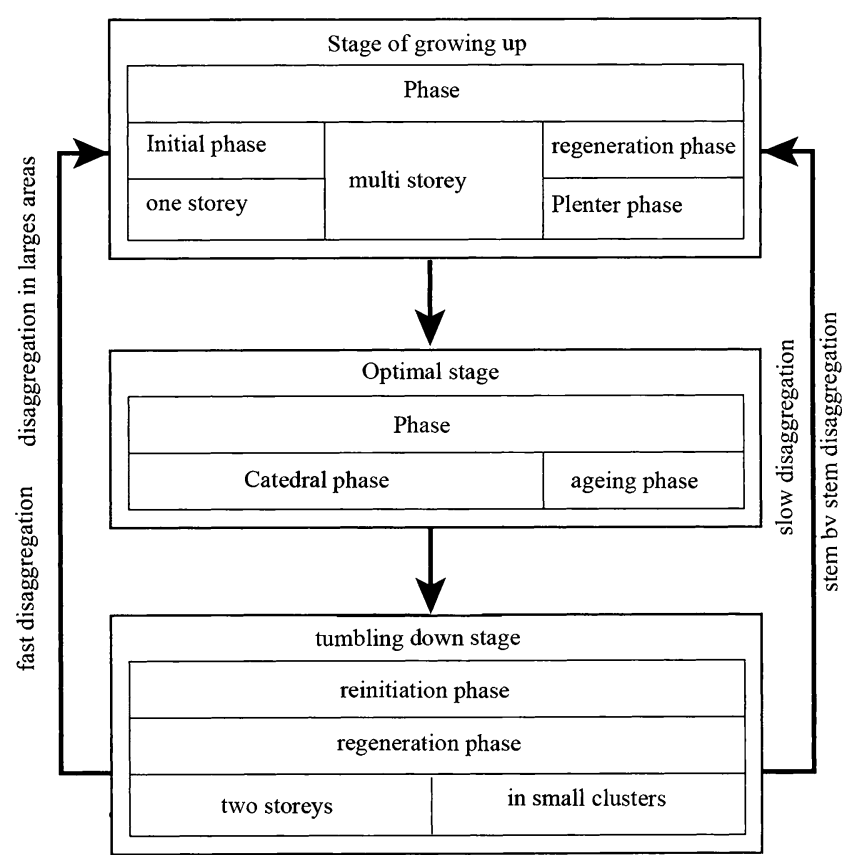

Fig. 1 General scheme of stages and phases of the ontogenic development of pristine forest. After Korpel' (1995) (slightly simplified) 


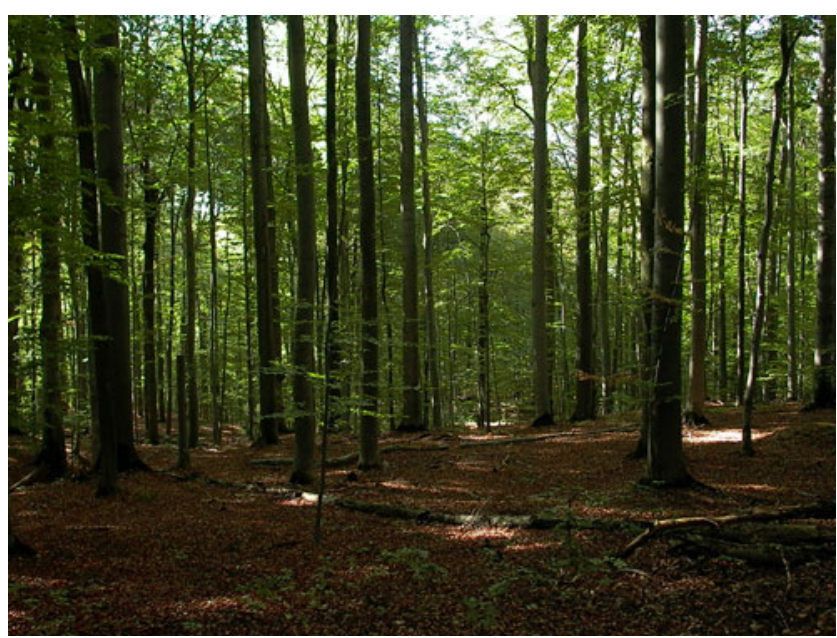

Fig. 2 Photograph of optimal phase in beech virgin forest Havešova, emphasizing the archetypical regular full closed stand structure, socalled cathedral structure in this phase and the small quantity of decayed trees on the floor

generational waves (used terminologically as cohorts in the present work albeit presenting some age variation, but evolving ontogenetically as more or less the same collective). The variety and variability of this irregular cover opening process, as well as the random occurrence of disturbances, create high forest structure diversity at this stage. In the case of the natural forest ecosystems of central temperate Europe, the main disturbing agent is the wind (Splechtna et al. 2005; Nagel and Diaci 2006), occurring in time intervals that are, as a rule, shorter than the average longevity of tree species and generating the spatial arrangement of closure openings. Medium-size windthrow disasters arising from local storms are a significant part of the disturbance regime of mixed natural forests of central Europe (Nagel and Diaci 2006; Nagel et al. 2007; Nagel and Svoboda 2008; Zuckrigl 1991). Depending on their size they are mostly weak- to medium-intensity disturban-

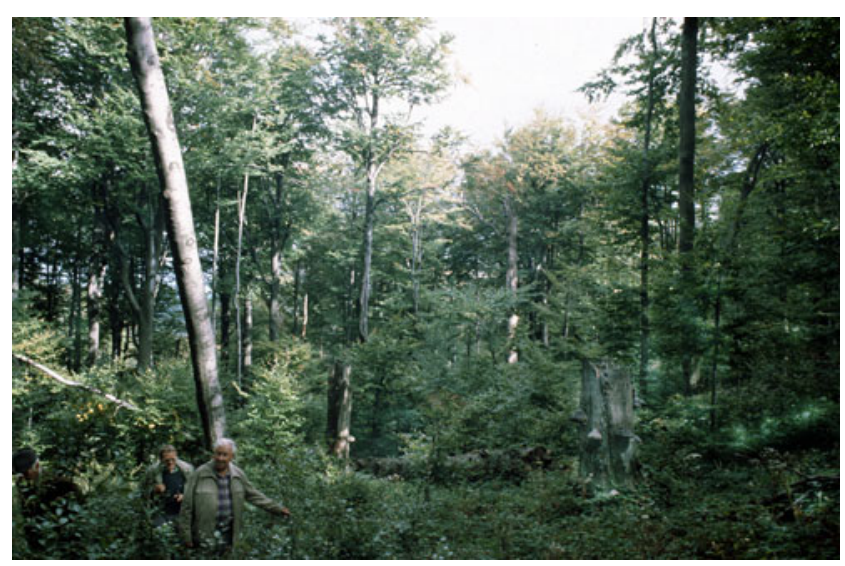

Fig. 3 Photograph of the tumbling down phase in virgin beech forest Kyov. In this case, the opening is about 0.5 ha. Forefront (right) Prof. S. Korpel' ces with typical log-normal distribution of frequencies of canopy gaps (Zeibig et al. 2005).

In short, regeneration under shelter can access the upper storey through canopy loosening by newly created opening patches or enlarged ones. Age analyses document that the duration of the life cycle for one generation (cohort) is in the case of beech about 250 years (Korpel' 1995). Studies of gap distribution in such forests exhibit an exponential negative distribution of the gaps and convey no particular aggregation pattern, giving evidence of the randomness of such a process (Drössler and von Lüpke 2005; Zeibig et al. 2005; Kucbel et al. 2010). A similar ontogenic pattern applies to pure spruce forests, with the difference that the life cycle lasts longer (300-350 years) and consequently the optimal phase is more expressed (80-100 years) and the disintegration openings are even wider, up to 1 ha (Korpel' 1995; Zuckrigl 1991).

The aim of the present study was to characterize the space-density relationship of the first cohorts. A comparison with a fully closed stand model (maximal density) as presented in a previous work (Schütz and Zingg 2010) permits the proportion of stand closure release to be determined, hence this can be associated with the risk determination. Fully closed stands have been modelled on the basis of Reineke's stand density rule, slightly modified and parameterized with fully stocked untouched plots from Switzerland and Slovakia.

\section{Material and methods}

We consider surveys of essentially stem number distribution repeatedly measured at long-term research plots in five pristine beech reserves (Havešova, Kyjov, Rožok, Stužica, Oblik) and four spruce reserves (Kosodrevina, Polana, Babia Hora und Pilsko) in Slovakia, where such permanent experimental plots have been established since 1960 under the initiative of Professor Š. Korpel' from the Institute of Silviculture at the Technical University in Zvolen. Some similar permanent plots from a corresponding Swiss beech virgin forest (St-Ursanne) established by the former Institute of Silviculture of the Swiss Federal Institute of Technology Zurich [Eidgenössische Technische Hochschule (ETH) Zürich] have been included as well as data of untouched stands from the permanent yield database of WSL (Swiss Federal Institute for Forest Snow and Landscape Research, Birmensdorf); see Schütz and Zingg (2010) for more detail. In each reserve, permanent plots have been established in three to five representative ontogenetic phases in accordance with the classification of Korpel' (1995) to cover the whole life cycle ontogeny. Table 1 gives an overview of the distribution of the available surveys. Altogether, there were 96 surveys for beech and 146 for spruce. 
Table 1 Survey characteristics

\begin{tabular}{lllll}
\hline Beech & & & & \\
\hline Type of survey & $\begin{array}{l}\text { Number } \\
\text { of sites }\end{array}$ & $\begin{array}{l}\text { Number of } \\
\text { phases }\end{array}$ & $\begin{array}{l}\text { Number of } \\
\text { remeasurements }\end{array}$ & Sum \\
\hline $\begin{array}{l}\text { Slovakian pristine } \\
\text { reserves }\end{array}$ & 4 & $3-5$ & $4-5$ & 52 \\
$\begin{array}{l}\text { Swiss pristine forest } \\
\begin{array}{l}\text { Yield plots untouched } \\
\text { stands }\end{array}\end{array}$ & 1 & 4 & 3 & 12 \\
$\begin{array}{l}\text { One time plots } \\
\text { Sum }\end{array}$ & 6 & & $5-17$ & 26 \\
$\begin{array}{l}\text { Spruce } \\
\begin{array}{l}\text { Slovakian pristine } \\
\text { reserves }\end{array}\end{array}$ & 4 & 5 & & 6 \\
$\begin{array}{l}\text { Yield plots untouched } \\
\text { stands }\end{array}$ & 6 & & $3-4$ & 96 \\
$\begin{array}{l}\text { One time plots } \\
\text { Sum }\end{array}$ & 33 & $3-13$ & 47 \\
\hline
\end{tabular}

${ }^{a}$ Ammann (2004)

The single plot size for the Slovak experimental plots is usually 0.5 ha (in some case 1 ha). The Swiss ETH plots have sizes ranging from 0.43 to 0.91 ha, and the size of WSL plots is 0.25 ha. The size of the Amman plots is 0.10 ha. On all the plots, every tree larger than $7 \mathrm{~cm} \mathrm{dbh}$ has been recorded accurately in millimeters crosswise with a calliper. Measurements were carried out about every 10 years in the permanent plots.

The developmental stage has been assessed for each chronoseries according to the criteria given in Korpel' (1995); see Fig. 1 for a definition of different phases and stages. In the case of the Slovakian plots, the determination was done by Korpel' himself. For the Swiss virgin-forest plots, developmental stage was determined by J.-P.S. according to the same criteria and the same assessment procedure. The assessments were considered essentially sufficient for a rough characterization of stand ontogenetic development.

Successive regeneration waves in virgin forest can be identified easily from the stem number distribution in $4 \mathrm{~cm}$ classes (see Fig. 4), at least in our material. Therefore, it seems realistic to follow the fate of single regeneration waves (cohort). In advanced stages of stand disintegration (tumbling down stage), an exact distinction of the original cohort is not evident in every case. For these stages, availability of repeated surveys is helpful in making such a distinction. For each survey, the first cohort was identified visually from the stem number histograms. Because in practice there is little information about age in reserves, the corresponding values were derived from the age-to- $d_{\mathrm{g}}$ relationship from 36 (and/or 37) WSL plots. For beech, in order to cover a sufficient age distribution, data of nine old shelterwood stands from Freist (1962) were included,
$\mathrm{N} / \mathrm{ha}$

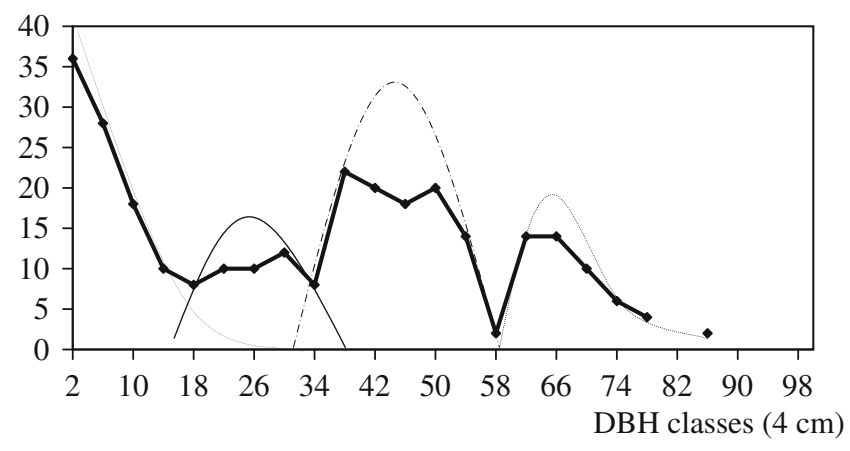

Fig. 4 Distinction of different waves of regeneration (cohorts) in the stem number distribution in one plot $(0.5 \mathrm{ha})$. Shown here for the pristine beech forest Kosodrevina, plot II, 1996. Four successive regeneration waves are distinctly perceptible

covering an age span of up to 140 years. Furthermore, we assume that maximum age is attained at maximum diameter (beech 250 years: $115 \mathrm{~cm}$; spruce 350 years: $130 \mathrm{~cm}$; $d_{\mathrm{g}}$ is the quadratic mean diameter for the corresponding cohort). The equation for fitting age $(A)$ with known $d_{\mathrm{g}}$ is a second grade polynomial for beech and a straight line for spruce, with the following formulation formulas:

For beech : $\mathrm{A}_{\mathrm{be}}=\alpha_{\mathrm{be}}+\beta_{\mathrm{be}}{ }^{*} \mathrm{~d}_{\mathrm{g}}+\gamma_{\mathrm{be}} *\left(\mathrm{~d}_{\mathrm{g}}\right)^{2}$

with the parameter values $\alpha_{b e}=16.3957, \beta_{b e}=2.57264$, $\gamma_{\text {be }}=-0.00534327$.

For spruce $: \mathrm{A}_{\mathrm{sp}}=\alpha_{\mathrm{sp}}+\beta_{\mathrm{sp}} * \mathrm{~d}_{\mathrm{g}}$

with the parameter values $\alpha_{\mathrm{sp}}=-1.3865 ; \beta_{\mathrm{sp}}=2.6427$.

This is a relatively rough assessment, but considering the long life cycle and, under our assumption about the end point, the interpolation appears sufficient for this kind of approximation.

Regression analysis (generally GLM procedure) was processed using the SYSTAT statistics package for Windows (Systat Software; http://www.systat.com/). The distribution of residuals was controlled visually and found to be appropriate in every case. The quality of the fitting was enhanced with the $t$-statistic of the standard partial regression coefficient tolerance of the variables, which is representative of their usefulness in the model and the corresponding $P$-tail of the transgression-probability $(P)$.

Descriptions of the site conditions of the different experimental virgin forest areas are as follows.

For beech: Reserve Havešova (170 ha) in the Bukov mountain region in Slovakia: altitude: $500-600 \mathrm{~m}$ a.s.l.; aspect: south; suboceanic climate: slightly continental with $\mathrm{N}=700-800 \mathrm{~mm} /$ year; mean annual temperature: about $7^{\circ}$ C; parent rock: flysch; soil type: cambisol. Reserve Kyjov (53 ha) in the Vyhorlat Mountains: altitude: $700-820 \mathrm{~m}$ a.s. 
1.; aspect: north, gentle slope; precipitation $\mathrm{N}=750$ $800 \mathrm{~mm} /$ year; temperature: about $6^{\circ} \mathrm{C}$; parent rock: andesite (volcanic); soil type: cambisol. Reserve Rožok (67 ha) in the Bukov mountains: altitude: $500-790 \mathrm{~m}$ a.s.l.; aspect: north; slope: $40-50 \%$; $\mathrm{N}=780 \mathrm{~mm} /$ year; $\mathrm{t}=6^{\circ} \mathrm{C}$; parent rock: sandstone with slightly calcareous binders and some clay schist; soil: mesotrophic cambisol. Reserve Stužica (659 ha) in the Bukov mountains at the edge between the west and east Carpathians: altitude: $650-900 \mathrm{~m}$ a.s.l.; aspect: north, gentle slope; $\mathrm{N}=850-1,000 \mathrm{~mm} /$ year; $\mathrm{t}=5$ $6^{\circ} \mathrm{C}$; parent rock: grey mica sandstone intermixed with dark clay; humic soil. Reserve Oblik (91 ha): altitude: 700930 m a.s.l.; parent rock: andesite; soil: ranker.

Swiss reserve St-Ursanne in Tariche (Haute-Côte) in the Jura mounts ( 9 ha): altitude: $700-800 \mathrm{~m}$ a.s.l.; northwest slope $40 \%$; $\mathrm{N}=1,265 \mathrm{~mm} /$ year; $\mathrm{t}=7.6^{\circ} \mathrm{C}$; parent rock: limestone; soil: rendzina; phytosociology: Cardamino Fagetum.

For spruce: Reserve Kosodrevina, on the south flank of the Chopok mountains: altitude 1,380-1,430 m a.s.l.; aspect: south; slope: $20-25 \%$; $\mathrm{N}=1,150-1,200 \mathrm{~mm} /$ year; $\mathrm{t}=1.5-2^{\circ} \mathrm{C}$; crystalline parent rock; humic podsol. Reserve Polana, forest district Kriván ( 685 ha): altitude between 560 and 1,458 $\mathrm{m}$ a.s. 1.; parent rock: andesite with some tuff; aspect: east to west; $\mathrm{N}=900-1,000 \mathrm{~mm} ; \mathrm{t}=4-4.5^{\circ}$; grey cambisol. Reserve Babia Hora in the western Beskids (117 ha): elevation: 1,1001,725 m a.s.l.; parent rock: calcareous sandstone and Magura flysch; $\mathrm{N}=1,600 \mathrm{~mm}<$ year; $\mathrm{t}=2^{\circ} \mathrm{C}$.

\section{Results}

The main analysis deals with the space-density relationship $N$-to- $d_{\mathrm{g}}$ of the main cohort according to Reineke's rule, slightly modified after Schütz and Zingg (2010); see Fig. 5, fitted with the equation:

$N=\alpha^{\prime *} e^{\beta^{*} \ln \left(d_{g}\right)+\gamma^{*}\left[\ln \left(d_{g}\right)\right]^{2}}$

or, after double logarithmic transformation

$\ln (\mathrm{N})=\alpha+\beta^{*} \ln (\mathrm{dg})+\gamma^{*}[\ln (\mathrm{dg})]^{2}$

where $\alpha^{\prime}=\mathrm{e}^{\alpha}$ with the following parameter values for beech

$$
\begin{aligned}
\alpha_{\mathrm{be}}^{\prime}= & 7951.0397 ; \beta_{\mathrm{be}}=0.71418217 ; \gamma_{\mathrm{be}}=-0.343293828 \\
& \times\left(\mathrm{N}=98, \mathrm{R}^{2}=0.983: \mathrm{p} \beta_{\mathrm{be}}=0.00260, \mathrm{p} \gamma_{\mathrm{be}}=0.0000\right)
\end{aligned}
$$

for spruce

$$
\begin{aligned}
\alpha_{\mathrm{sp}}^{\prime}= & 1145.0394 ; \beta_{\mathrm{sp}}=2.15744441 ; \gamma_{\mathrm{sp}}=-0.6650788 \\
& \times\left(\mathrm{N}=139, \mathrm{R}^{2}=0.983: \mathrm{p} \beta_{\mathrm{sp}}=0.0000, \mathrm{p} \gamma_{\mathrm{sp}}=0.0000\right)
\end{aligned}
$$

In analogy with Reineke's rule, Fig. 5 presents, for beech plots, the $\ln N$-to-ln $d_{\mathrm{g}}$ relationship for the original cohort for virgin pure beech forests. For comparison, the trajectory for untouched fully stocked stands is displayed with a function after Schütz and Zingg (2010). This function was determined for fully closed untouched yield plots, and some fully closed primeval forests growing in comparable site conditions in the two countries considered.

The function for fully stocked stands after Schütz and Zingg (2010) displays the following parameter values for beech:

$\alpha_{\text {befull }}^{\prime}=11274.6449 ; \beta_{\text {befull }}=0.45703518 ; \gamma_{\text {befull }}=-0.389943317$;

and for spruce:

$\alpha_{\text {spfull }}^{\prime}=8221.33 ; \beta_{\text {spfull }}=0.647461 ; \gamma_{\text {spfull }}=-0.38065$.

Figure 6 presents the density relationship in terms of basal area $(\mathrm{G})$ versus $d_{\mathrm{g}}$ for the case of spruce. It is derived from Function 4 , whereby $\mathrm{G}=\pi / 4 * d_{\mathrm{g}}^{2}$. It illustrates more realistically the course of stand closure as well as a relatively wide variation of single values. In this case, plots particularly injured by bark beetle (Ips typographus) attacks are enhanced.

Figures 7 and 8 depict the basal area versus age for both species; age is determined according to Functions 1 and 2.

Finally, risk $(R)$ of disclosure as presented in Fig. 7 can be calculated as

$\mathrm{R}=1-\left(\mathrm{G}_{\text {observed }} / \mathrm{G}_{\text {full }}\right)$

\section{Discussion}

Figures 5 and 6, expressing the stand density according to numbers of trees and basal area of the upper storey of the primary cohort, respectively, convey some variations of the values. This is not unexpected for the following reasons: stand closure release in an ageing forest ought to be a versatile phenomenon because different disturbance factors could be involved and interact with predisposing factors such as timber decay due to ageing. In temperate central Europe, the main disturbance is considered to be windstorm (Hanewinkel et al. 2011). Its occurrence seems to be very stochastic (Dobrovolny and Brízdil 2003; Bielec-Bąkowska 2003; Schütz et al. 2006). It does not occur at such high frequency as on the Atlantic coast or in northern Europe (Schiesser et al. 1997) and there seem to be regional differences in storm injuries, which explains the difference in the maximal gap size (Zeibig et al. 2005). A part of the variation could be due to differences in the yield level potential, that is, the fact that, for the same site index, there could be important residual variation of the main yield factors (Schütz and Zingg 2010) due to different space utilization. Yield level is manifested mainly in the 
Fig. 5 Scatter plot of the sizedensity values $N$ in relation to the quadratic mean diameter $d_{\mathrm{g}}$ for pure beech pristine forests plots of different stages

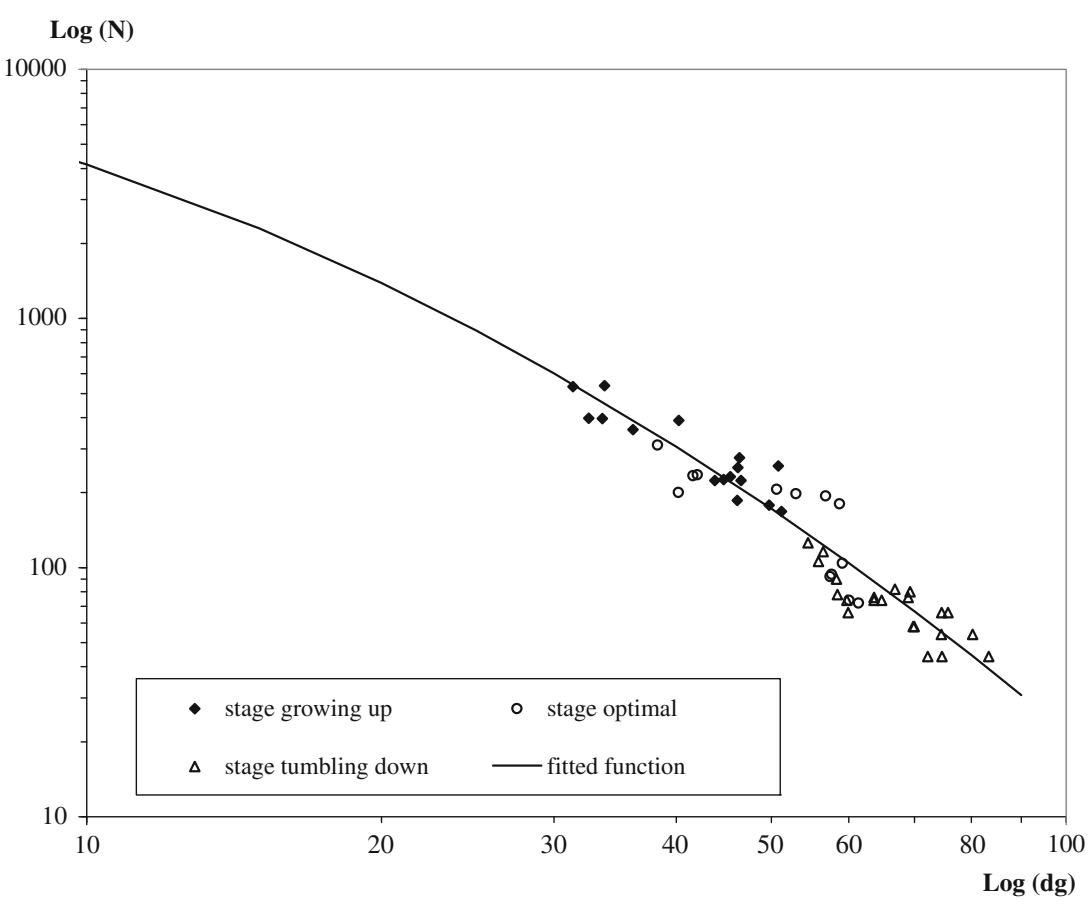

variation of the maximum basal area, as can be seen in the middle part of the graph, representing more or less fully stocked stands corresponding to the optimal phase.

Whether it is possible to distinguish the intermixing of different cohorts on plots of 0.5 ha needs critical attention. This is hardly unproblematic for fully closed plots in the growing up stage and optimum stage, as well as for

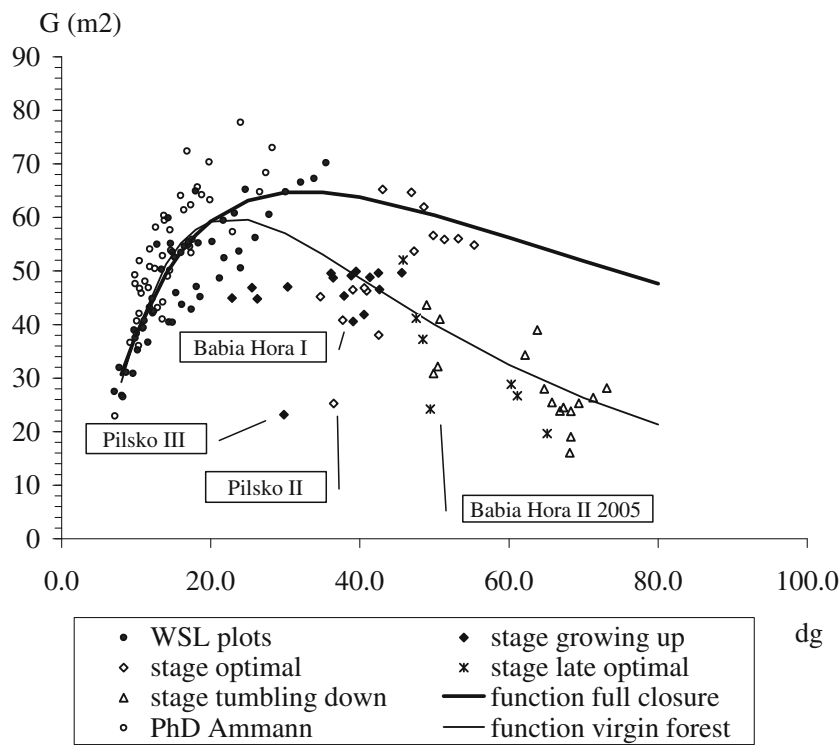

Fig. 6 Basal area according to quadratic mean diameter for spruce plots. Stands having been heavily injured by bark beetle are highlighted. The bold line represents the trajectory for full closure, derived from the model by Schütz and Zingg (2010). Mean line is the average fitted function for virgin spruce forests reference plots from untouched surveys where whole stem numbers were considered. In the first stage of stand release (tumbling down), a distinction of two cohorts was obvious in every case. More attention should be given to advanced release stages. Generally, a clear distinction between more cohorts was possible as shown in Fig. 4. A very small scale

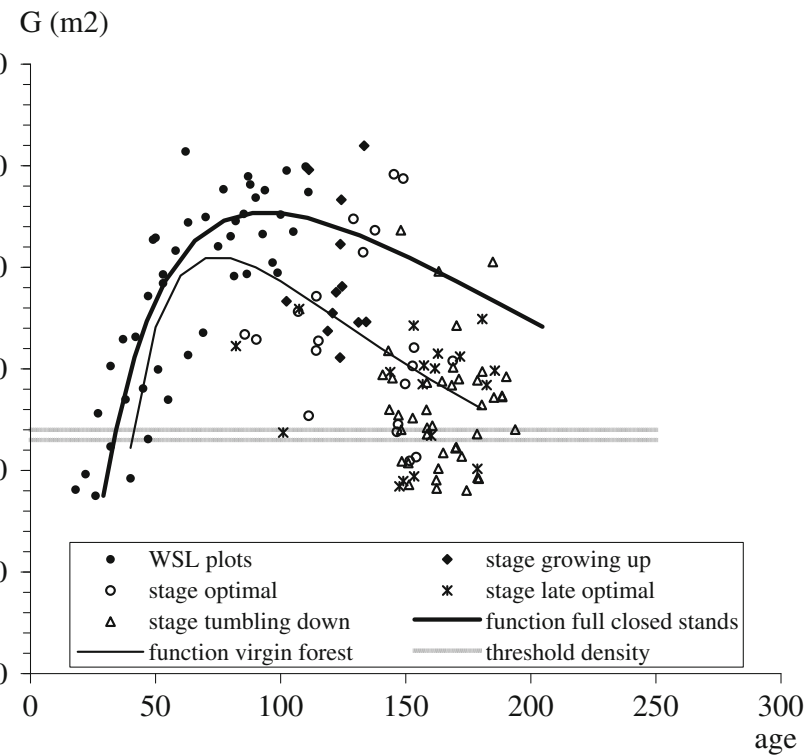

Fig. 7 Age-related basal area trajectory for all beech plots. The bold line represents the trajectory for full closure according to the model after Schütz and Zingg (2010). The mean line is the fitted function for virgin forests plots. The threshold for density allowing the new generation accessing correctly to the upper storey according to sylvicultural expertise is given by the two horizontal lines 


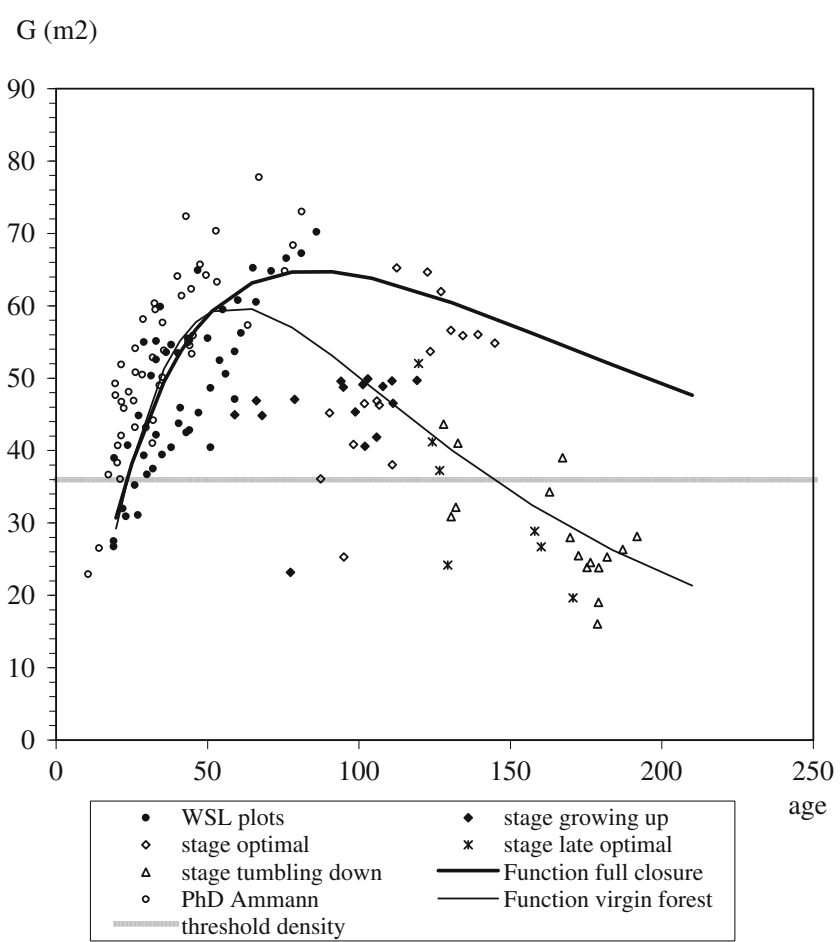

Fig. 8 Age-related basal area trajectory for the spruce plots. See legend to Fig. 7 for definitions

intermixing of stem dimensions, somewhat comparable with the classical plenter phase, never occurred. In a few cases, it was not absolutely obvious whether different cohorts or remnants of the same cohort were present. The fact that our plots have been repeatedly remeasured over 40 to 50 years helps us to decide more objectively. Extrapolations of the trend lines lead to interception of the $x$-axis at approximately the maximum diameter, at about 110 $120 \mathrm{~cm}$ dbh for beech and 130 for spruce (Holeska et al. 2009). Thus, the fitted trend lines are very coherent and corroborate our hypothesis that, at the end of the life cycle, expressed as maximal dbh (or age), the whole cohort has been replaced.

Figure 9 corroborates that the risk of stand closure release of spruce is substantially higher (about $40 \%$ ) than that of beech because its longevity is superior by $40 \%$. This could be seen as a result of the differences in vulnerability to storm, which was found to be 2.7 to 3 times higher in spruce than in beech (Schütz et al. 2006). Moreover, beech is shorter living because of its higher sensitivity to decay (Shigo 1976). Korpel' (1995, p 143) mentions that newly created gaps in pristine beech forests are often apparently caused by timber infected by fungi. This view is corroborated by Zuckrigl (1991). This apparent contradiction suggests a somewhat different analysis. In fact longevity does not equal stability but depends on many other biotic factors, such as aptitude to resist decaying, that is, by creating a defence compart-

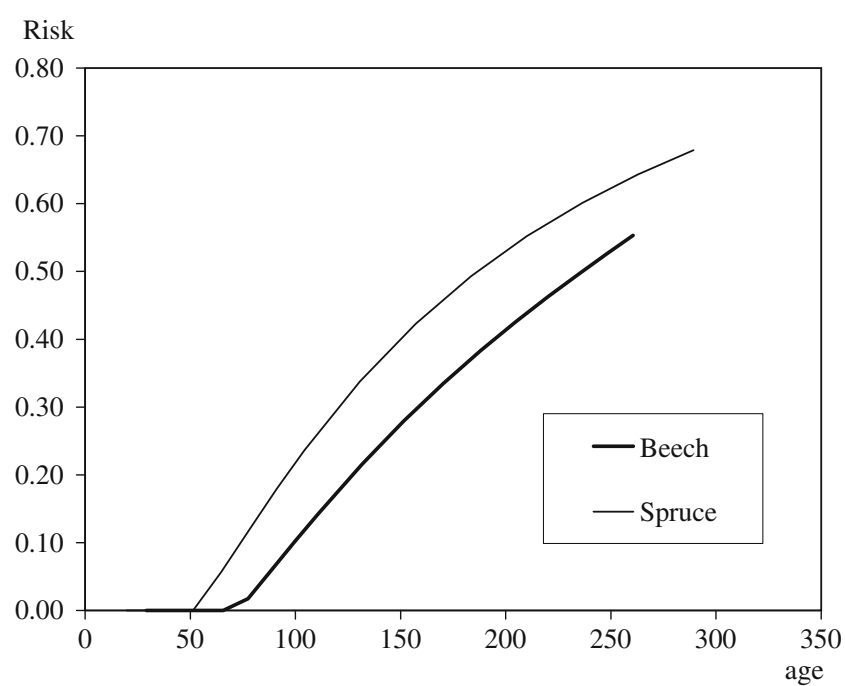

Fig. 9 Age-related stand release risk for beech and spruce virgin forests. Risk $0.0=$ Full closure; Risk $1.0=$ whole stand disrupted

ment in the trunk or other defence mechanisms. Decay does not seem to be the decisive factor, almost until advanced ageing. Thus, with increasing age, less important storms can lead to more disturbances. The exponential form of the disclosure function in Fig. 9 supports this interpretation.

The difference between beech and spruce lies not only in their different longevities; spruce also utilizes the available space twice as efficiently (Pretzsch and Schütze 2005), which leads to much more dense and dark stands in the optimal phase. In such spruce forests, full cover lasts longer because of a close dampening contact of neighbors (collective stability); however, because of the high single stem vulnerability, once the stand cohesion dismantles, the stand tumbles down over much greater areas (Zuckrigl 1991). Until now, risk, particularly of storm damage, has been considered more or less only for healthy forests because weakened trees injured by decay or other factors have been removed intentionally before, or at least during, the previous hazard event. Even then the question of stand vulnerability should consider not only the mechanical constraints of individual trees, but also something like a collective effect on stability due to the imbrications of trees within a stand, as the waving of single trees is dampened by neighbors. Ivanov (2007) showed experimentally in the case of static resistance of pine stands that neighbors contribute to a substantial dampening and thus allow tree flexion curbing. Collective stand stability should be interpreted while considering the whole grid constituted by networking trees, resembling a carcass effect in which stable trees or skeleton trees play a major role. Vanomsen (2006) showed for adult spruce trees that anchoring of the most stable one is three- to four-times more resistant than that of the average. The carcass effect is based on a network 
of skeleton trees and works as long as this grid still functions. Schütz et al. (2006) showed that, after a main storm event, e.g., the storm "Lothar", the point after which the stand collective substrate no longer works seems to be around a cover of 0.5 , and that below this point cohesion would loosen. From the point of view of air flow, a nonregular opening of the cover seems to be critical for stand disintegration, as wind tunnel experiments of Gardiner et al. (1997) show, along with the formation of closure openings in large patches (more than one tree height).

Below the age of 50 years for spruce and 70 years for beech, the risks can be considered as imperceptible (Fig. 9). Assuming an age of 120 years as the maximal conventional rotation age for managed forests, the stand closure release risk then reaches $17 \%$ for beech and $30 \%$ for spruce. We assume that the first stage of changes in the stand constitution should correspond to stemwise mortality. For beech, this interpretation is based on the results of gap distribution studies in two of the same virgin forests as in our study (Drössler and von Lüpke 2005; Kucbel et al. 2010) or comparable ones (Zeibig et al. 2005). They exhibit a strong exponential gap size distribution with a high dominance of small gaps created by the die-off of single or few trees. From the point of view of stand dynamics, as well as vulnerability to storms, these small gaps are not as pertinent. They act on the stand structure like a thinning and the cover closes up relatively quickly in the following period (Kucbel et al. 2010). A demonstration of expertise from the so-called Seebacher shelter thinning, a very heavy thinning in beech forest at the end of the nineteenth century, corroborates this conclusion. In these interesting practical experiences, when basal area was reduced regularly by as much as $60 \%$ in one extremely heavy thinning, the cover release did not allow the undergrowth to reach the upper storey, because the cover closed again 40 years later (Dittmar 1991).

From the point of view of biodiversity, it may be of interest to discuss the effect of stand closure release on natural structure formation in virgin forests by intermixing the different regenerational waves, considering the cover opening needed to allow a second growth. The determinant for new recruitment is a sufficient reduction of cover, or basal area, by the formation of sufficiently large patches. This is particularly valid for beech, which belongs to the most light-intercepting species. Therefore, we consider that only larger opening patches allow the local growing up of the following regeneration wave to reach the upper storey with enough stability. Silvicultural knowledge supports this interpretation. Conventional wisdom in beech irregular forestry is that a basal area of about $20 \mathrm{~m}^{2}$ constitutes a threshold density allowing a well-sustained balance between the different storeys (Schütz 2006; Turckheim and Bruciamacchie
2005). Similarly, silvicultural experience of the shelterwood cutting system shows that reduction of the basal area to below $18-16 \mathrm{~m}^{2}$ is necessary to ensure a qualitatively and developmentally sufficient recruitment to ensure a valid new generation (Freist 1962) and that, in the long run, the basal area reduction needs to drop below $12 \mathrm{~m}^{2}$ when the second growth attains the development of the pole stage. In the group regeneration system (so-called Femelsystem), which, for a species like beech, is quite an efficient light-regulating system, an opening size of about 1-2 tree heights seems necessary (Schütz 1998). A combination of regular shelterwood and gaps could be considered even more efficient (Fröhlich 2011). Such a threshold stand density to ensure sustainability is corroborated with single tree irregular forest (beech plenter forest), where a basal area of $20-21 \mathrm{~m}^{2}$ is shown to be necessary for sustainable recruitment (Schütz 2006).

According to these considerations, we can assume that a basal area of about $20 \mathrm{~m}^{2}$ is the optimal threshold density to ensure qualitatively valid up-growth of a new generation; Figs. 7 and 8 show that this is attained at the age of about 200 years for beech. Considering that, at a basal area of $27 \mathrm{~m}^{2}$, recruitment stalled in beech plenter forest in Thuringia (Schütz 2006), we can assume that a basal area of 23-24 $\mathrm{m}^{2}$ represents the realistic threshold limit for accession of second growth. Thereafter, it is attained for virgin beech forests at the age of 180 years. This means that about $70 \%$ of these forests lie beyond the limit for optimal and, in particular, sustainable recruitment.

Spruce stands convey a similar figure with the difference that the duration of the life cycle is $40 \%$ longer. A small number of density values exhibit particularly low densities, far below the trendline (see Fig. 6). This is due to bark beetle attacks, which, in certain years, dramatically affect such forests. After such attacks, the forest can recover well, but with reduced density, which can lead temporarily to plenter structures, as stated by Korpel' (1995). For spruce, expertise in transformation from plantation forest into irregular plenter structures in the Swiss Jurassic mountains shows that a basal area of about $35-37 \mathrm{~m}^{2}$ reduces recruitment significantly, whereas $33 \mathrm{~m}^{2}$ represents the optimal density for sustainable recruitment (Schütz and Röhnisch 2003). Thus, it can be assumed that threshold density conditions of about $36 \mathrm{~m}^{2}$ would be attained in pristine spruce forest at the age of 140 years (which corresponds to $40 \%$ of the whole life cycle).

\section{Conclusion}

A comprehensive picture of pristine forest dynamics relies essentially on an understanding of the disclosure mecha- 
nisms, and particularly the formation of larger disclosure patches that allow the imbrication of new reiteration waves which are decisive for vertical structure. How ageing operates on stability appears to be the key to such an understanding. Natural longevity exerts an important influence as it characterizes the increasing vulnerability of forest stands. A comparison with knowhow from traditional forestry suggests that vulnerability should be considered as a gradual (discrete) rather than continuous phenomenon depending on a complex relationship between the collective cohesion within a stand and propensity to weakening factors. There are great similarities between the two species beech and spruce, mainly in the mechanism of their vulnerability and less in their space-time occurrence.

Acknowledgments We are very grateful to the Swiss Federal Institute for Forest Snow and Landscape Research (WSL), Birmensdorf, Switzerland, and particularly to Andreas Zingg for making available the data from the yield data base.

\section{References}

Ammann PL (2004) Untersuchung der natürlichen Entwicklungsdynamik in Jungwaldbeständen: Biologische Rationalisierung der waldbaulichen Produktion bei Fichte, Esche, Bergahorn und Buche. PhD thesis Nr. 15761, ETH, Zürich

Bielec-Bąkowska Z (2003) Long-term variability of thunderstorm occurrence in Poland in the 20th century. Atmos Res 67-68:3552

Dittmar O (1991) Der Seebach'sche Lichtungsbetrieb: Ein interessanter Aussenseiter der Buchenwirtschaft des 19. Jahrhunderts. Der Wald (Berlin) 41:165-168

Dobrovolny P, Bŕźzil R (2003) Documentary evidence on strong winds related to convective storms in the Czech Republic since AD 1500. Atmos Res 67-68:95-116

Drössler L, von Lüpke B (2005) Canopy gaps in two virgin beech forest reserves in Slovakia. J For Sci 51:446-457

Dursk J (1997) Modellierung der Absterbeprozesse in Rein- und Mischbeständen aus Fichte und Buche. Allg Forst Jagdeztg 168:131-134

Freist H (1962) Untersuchungen über den Lichtungszuwachs der Rotbuche und seine Ausnutzung im Forstbetrieb. Beiheft Forstwiss. Cbl. 17, München, p 78

Fröhlich FS (2011) Economic and ecologic advantages of small scale structured beech close to nature forest management: the case of group selection system. Zbornik gozdarstva in lesarstva 94:55-66

Gardiner BA, Stacey GR, Belcher RE, Wood CJ (1997) Field and wind tunnel assessments of the implications of respacing and thinning for tree stability. Forestry 70:233-252

Hanewinkel M, Hummel S, Albrecht A (2011) Assessing natural hazards in forestry for risk management: a review. Eur J For Res 130:329-351

Holeska J, Saniga M, Szwagrzyk J, Czerniak M, Staszynska K, Kapusta P (2009) A giant tree in the West Carpathians: an exception or a relic of formerly widespread mountain European forests? For Ecol Manage 257:1577-1585

Ivanov DE (2007) Stabilité et résistance individuelle et collective et phénomènes de désintégration collective face aux sollicitations de neige lourde au sein de peuplements de pin sylvestre (Pinus sylvestris L.): analyse et gestion du risqué de dégâts, conséquences pour la pratique d'éclaircies tardives. Thesis ETH Nr 17513, Zürich, p 237

Korpel' Š (1995) Die Urwälder der Westkarpathen. Fischer, Stuttgart

Kucbel S, Jaloviar P, Saniga M, Vencurik J, Klimaš V (2010) Canopy gaps in an old-growth fir-beech forest remnant of Western Carpathian. Eur J For Res 129:249-259

Leibundgut H (1959) Über Zweck und Methodik der Struktur und Zuwachsanalyse von Urwäldern. Schweiz Z Forstwes 110:111124

Lonsdale WM (1990) The self-thinning rule: dead or alive. Ecology 71:1373-1388

Mayer H (1978) Über die Bedeutung der Urwaldforschung für den Gebirgswaldbau. Allg Forstz 24:691-693

Moorby J, Wareing PF (1963) Ageing in woody plants. Ann Bot 27:291-308

Nagel TA, Diaci J (2006) Intermediate wind disturbance in an oldgrowth beech-fir forest in southeastern Slovenia. Can J For Res 36:629-638

Nagel TA, Svoboda M (2008) Gap disturbance regime in an oldgrowth Fagus-Abies forest in the Dinaric Mountains. BosniaHerzegovina. Can J For Res 38:2728-2737

Nagel TA, Levanic T, Diaci J (2007) A dendroecological reconstruction of disturbance in an old-growth Fagus-Abies forest in Slovenia. Ann For Sci 64:891-897

Ozenda P (1994) Végétation du continent européen. Delachaux et Niestlé, Lausanne, p 271

Pintarič K (1978) Urwald Peručisa als natürliches Forschungslaboratorium. Allg Forstz 24:702-707

Pretzsch H (2006) Species-specific allometric scaling under selfthinning: evidence from long-term plots in forest stands. Oecologia 146:572-583

Pretzsch H, Schütze G (2005) Crown allometry and growing space efficiency of Norway spruce (Picea abies [L.] Karst.) and European beech (Fagus sylvatica L.) in pure and mixed stands. Plant Biol 7:628-639

Reineke LH (1933) Perfecting a stand density index for even-aged forests. J Agric Res 46:627-638

Schiesser H-H, Waldvogel A, Schmid W, Willemse S (1997) Klimatologie der Stürme und Sturmsysteme anhand von Radar- und Schadendaten. Schlussbericht Nation. Forschungs. Progr. 31, Vdf Hochschulverlag an der ETH, Zürich, p 132

Schütz JP (1998) Licht bis auf dem Waldboden: Waldbauliche Möglichkeiten zur Optimierung des Lichteinfalls im Walde. Schweiz Z Forstwes 149:843-864

Schütz JP (2006) Modelling the demographic sustainability of pure beech plenter forests in Eastern Germany. Ann For Sci 63:93-100

Schütz JP, Röhnisch F (2003) Steuerung des Nachwuchses während der Überführung von gleichförmigen FichtenAufforstungsbeständen in Plenterwälder. In: Kenk G (ed) Beiträge zur Jahrestagung 2003: Deutscher Verband forstlicher Forschungsanstalten, Sektion Ertragskunde, Freiburg i.Br. pp 184-194

Schütz JP, Zingg A (2010) Improving estimations of maximal stand density by combining Reineke's size-density rule and the yield level, using the example of spruce (Picea abies (L.) Karst.) and European Beech (Fagus sylvatica L.). Ann For Sci 67:507

Schütz JP, Götz M, Schmid W, Mandallaz D (2006) Vulnerability of spruce (Picea abies) and beech (Fagus sylvatica) forests stands to storms and consequences for silviculture. Eur J For Res 125:291302

Shigo AL (1976) Compartmentalization of discolored and decayed wood in trees. In: Material und Organismen. Dunker \& Humbolt, Berlin, pp 221-226 
Spellmann H (1999) Überführung als betriebliche Aufgabe. Forst Holz $54: 110-116$

Splechtna BE, Gratzer G, Black BA (2005) Disturbance history of a European old-growth mixed-species forest-a spatial dendroecological analysis. J Veg Sci 16:511-522

Turckheim B, Bruciamacchie M (2005) La futaie irréguličre; Théorie et pratique de la sylviculture irréguličre continue et proche de la nature. Edisud, Aix en Provence, p 282

Vanomsen P (2006) Der Einfluss der Durchforstung auf die Verankerung der Fichte hinsichtlich ihrer Sturmresistenz. Thesis ETH Nr 16532, Zürich, p 246
Weller DE (1987) A reevaluation of the $-3 / 2$ power rule of plant selfthinning. Ecol Monogr 57:23-43

Zeibig A, Diaci J, Wagner S (2005) Gap disturbance patterns of a Fagus silvatica virgin forest remnant in the mountain vegetation belt of Slovenia. For Snow Landsc Res 79:69-80

Zeide B (1985) Tolerance and self-tolerance of trees. For Ecol Manag 13:149-166

Zeide B (1987) Analysis of the $3 / 2$ power law of self-thinning. For Sci 33:517-537

Zuckrigl K (1991) Succession and regeneration in the natural forest in central Europe. Geobios (Jodhpur) 18:202-208 